\title{
Use and assessment of the 'new' rural functions by land- users and landowners of the Montado in Southern Portugal
}

\author{
Diana Surová, Teresa Pinto-Correia \\ University of Evora - ICAM, Mediterranean Landscape and Ecossystems, Evora, Portugal - \\ dj@uevora.pt
}

\begin{abstract}
The aim of the study presented here is to contribute to knowledge about how the Montado supports 'new' rural functions, connected to leisure and recreation activities, and how these can be improved. The Montado is an agrosilvopastoral system dominant in Southern Portugal. Due to its various types of uses, the Montado is recognizedly a multifunctional landscape, though future management conditions are still to be defined.

In order to ensure the development of rural areas, knowledge about the present state of 'new' functions is needed. While the issue can be tackled from different perspectives, the research presented here surveyed the use and the assessment that different land-users and landowners make of 'new' rural functions. A qualitative survey was carried out through 204 personal interviews with different types of land-users (rural and urban inhabitants, workers, tourists, hunters, mushroom pickers and bee-keepers) and 28 interviews with landowners. The interviewees responded to questions about the activities they carry out in the Montado, as well as existing difficulties and also possible improvements related with their activities. The landowners were asked to describe the current incorporation of 'new' functions in the management of their farms and their motivations to do so.

Results reveal that there is a variety of 'new' rural functions in the Montado, such as walking, hunting, mushroom picking and beekeeping. As to the main difficulties, problems were identified regarding access to private properties, a feeling of lack of security due to no information regarding wild cattle, hunting and fire and lack of facilities promoting orientation, such as the signposting of walking paths and tourist information. For landowners, inclusion of 'new' functions in their estate management was mainly influenced by economic motivation. Most landowners included hunting in the management of their estates. Few landowners perceived the 'new' activities as being no more than a complication for the purely productive management of their properties.

The present study highlights several aspects that are important for the successful inclusion of 'new' rural functions in the management of Montado private properties. Namely, the economic benefits that 'new' rural functions bring to landowners, the fact that qualified help is needed for landowners in the implementation process, and the importance of a clear definition of rights and responsibilities of landusers and landowners with regard to the functions mentioned.
\end{abstract}

Keywords: Montado, multifunctional use, land-users, landowners, property rights

\section{Introduction}

Nowadays, the increasing demand for the rural landscape as a space for leisure and recreation has raised interest in the Montado, the silvopastoral system characteristic of the Alentejo region. The landscape associated with this land use system is particularly attractive due to its combination of: a) open and tree covered areas, b) cleared and shrub-covered under-cover, c) human management that maintains a semi-natural aspect, d) the presence of livestock in low densities, e) the presence of wild flora and fauna, etc. (Gomez-Limon and Fernandez 1999). There are also new rural inhabitants who settled recently in the countryside and search for this type of landscape, and tourists who visit this specific system, with the purpose of contemplation, walking, riding, bicycle tours, etc. The most numerous amongst user-groups are possibly local people who visit the Montado occasionally for aesthetic satisfaction, recreational activities or other experiences that provide an escape from daily routine. Concerning urban people, we find both actual users and those who are interested in the system for its own sake, who acknowledge its value for many purposes, and who may be potential users of the Montado in the future. The Montado is thus nowadays appreciated in various ways that entail several non-productive functions. Nevertheless, present-day management is still focused on production, even if landowners are aware of the potential interest of the Montado for many other uses and for satisfying diverse human needs (Plieninger et al 2004). 
Due to its various types of uses the Montado is recognized as a multifunctional landscape (PintoCorreia and Vos 2004). However, future management conditions are still to be defined, due to changes in social demand, and to the threat of decrease in incomes generated by the production functions. Research can help in describing the current state of these functions and identifying existing or potential conflicts.

Since public involvement is considered as one of the instruments that help increase the successful management of rural areas (e.g. Konijnendijk, 2000), information on public demand and preferences is needed. This paper presents the results of a survey undertaken in the Alentejo region, in the area where the cork-oak Montado is dominant, concerning the use and assessment of 'new' rural functions in the Montado by its land-users and landowners, in order to obtain knowledge on how this system is valued from different points of view. The aim is to contribute to the future management of 'new' rural functions, or non-commodity functions, in the Montado by providing information about the present situation. Results regarding visitor profile, current activities practiced in the Montado, perceived limitations and improvements suggested by land-users, as well as landowners' attitudes towards these functions are presented and discussed.

\section{The Montado - a multifunctional system waiting for multifunctional management}

The idea of multifunctionality of rural landscapes is widely connected with providing social functions. These functions are not totally new, they have always been part of rural life, as for example picnicking or hunting. It seems however that the more urbanized lifestyle of contemporary societies claims for these functions in an innovative form. Besides recognizing the importance of the multifunctionality of landscape, both in the scientific community as also in the definition of policy objectives (e.g. the Second Pillar of the Common Agricultural Policy), a more concrete definition of steps towards achieving multifunctionality is needed.

In the Alentejo, the southern region of Portugal, large private farm units prevail. A dominant land use in this region is the agrosilvopastoral system known as Montado, which has existed for centuries in more or less developed and intensive management forms (Fonseca 2004). Its appearance is that of a generally open, savanna type, evergreen oak woodland. The dominant tree species are cork oak (Quercus suber, L.) or holm oak (Quercus ilex, spp. rotundilfolia, L.). Traditionally, this system has been exploited by multiple land uses, combining the exploitation of the tree cover, both for cork and wood for charcoal, and a rotation of grazing, cultivation and fallow in the undergrowth (Pinto-Correia 1993). The main products of the cork-oak part of the Montado are cork and meat from livestock breeding. Cereals used to be produced in the Montado until some decades ago, but have been disappearing, due to extensification trends (Pinto-Correia and Mascarenhas 1999). Where crops are grown today their purpose is to produce forage for the cattle. Nowadays, the system is therefore mainly a silvopastoral system. These production functions, maintained with no need for considerable investments, ensure an income for the landowners, as cork is highly valued in the market and cattle highly supported by the CAP.

Apart from these main productive functions, the Montado secures social functions for the local populations and for visitors, as it is used directly for instance by hunters, bee-keepers and mushroom pickers, as well as for those who take a walk in the countryside. Historically, the first group of functions was important for the rural population in supplementing food resources (Fonseca 2004). Today, hunting can be managed in two ways: through the municipal domain and hunting associations; or on a tourist basis, where estates are closed to other types of hunting and have an obligation to fulfil a game management plan, and where hunters from outside the area pay for this activity. This last modality can offer an economic supplement to landowners. Concerning bee-keeping, the Mediterranean vegetation communities in the Montado are rich with several aromatic plants, responsible for the high quality of honey in this region. As for mushrooms, the semi-open forest and the low intensity of soil mobilization create the conditions for a valuable development of mushrooms. Certainly, their richness also depends on the quality of the soils.

The main issue in this situation is that all these functions are appreciated by society, but do not contribute to the maintenance of the system - only livestock production and cork harvesting represent an income for landowners. If public policies targeting the possible maintenance of the Montado are to be defined, or improved, there is a need for more knowledge on the specificity of the social demand for this particular area. 


\section{Study area and method}

\section{Study area}

Four small towns in the north-western part of the region of Alentejo were selected as main centers for the interviewing process: Alcácer de Sal, Montemor-o-Novo, Évora and Coruche (Fig.1). These towns are situated in surroundings where the cork oak Montado dominates and has already a multifunctional use, which is carried out by local inhabitants and urban dwellers from the metropolitan area of Lisbon, as well as by foreign tourists. Furthermore, non-profit organizations in these towns supply information and contacts with land users and landowners.

The climate in the studied area has Mediterranean and continental characteristics, with a long dry season during very hot summers, fresh winters and a high amplitude of daily temperatures. The study area features a rippled plain, associated with extensive use and dominance of large estates (more than 200 ha) that combine cereal production (nowadays mainly for forage) and livestock grazing in open pastures or under the Montado tree cover, cork and wood production in the Montado, forest plantations of Eucalyptus globulus and of Pinus pinea, and more recently vine. In the municipalities of Alcácer de Sal and Coruche there are also rice plantations. The average annual temperature is $16,5^{\circ} \mathrm{C}$ and average annual precipitation $600-700 \mathrm{~mm}$.

Population density is low: in Alcácer de Sal 10hab/Km2; Montemor-o-Novo 15hab/Km2; Coruche $19 \mathrm{hab} / \mathrm{Km} 2$ and Évora 43,2hab/Km2, concentrated in towns or large villages, in a characteristic contrast between towns and the countryside. The total population has been decreasing steadily in the last decades, mostly in the dispersed farmsteads and smaller villages. As the region does not offer many alternative job facilities, younger people tend to leave when the extensive farming systems employ less and less people. Improving the multiple uses of the landscape, particularly in the specific Montado system, could be a way towards a more diversified economy and a higher social value of the region's rural attributes.

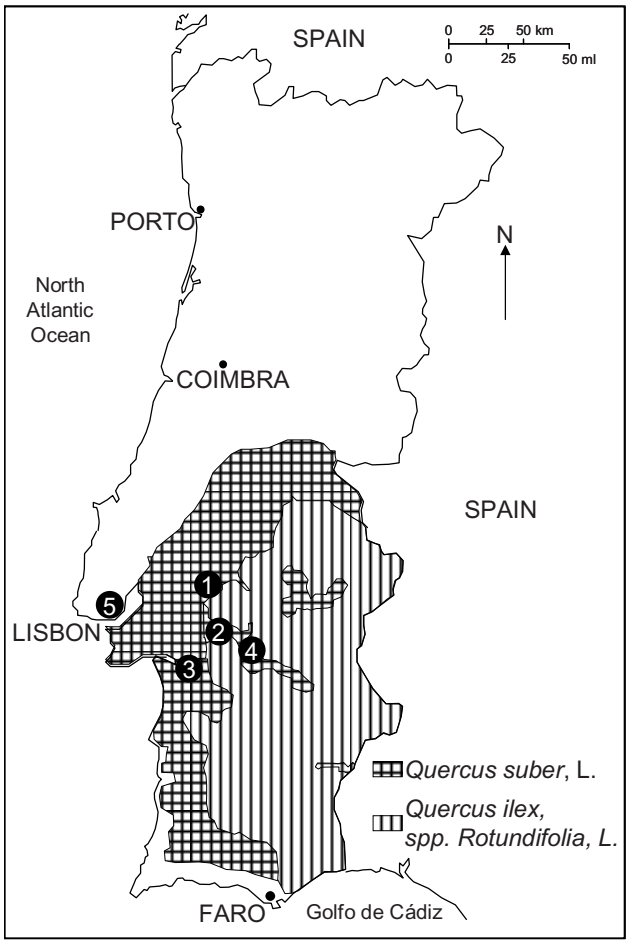

Figure 1. The main distribution of Cork Oak (Quercus suber, L.) and Holm Oak (Quercus ilex, spp. rotundilfolia, L.) in Portugal. The red points indicate the areas where the survey was carried out: the small towns of Coruche, Montemor - o -Novo, Alcácer de Sal and Évora. Lisbon is also indicated as the survey targeting urban dwellers was carried out there as well.

\section{Method}

An approach based on a qualitative research method using interviews was applied, in order to gain detailed information about use and evaluation of the Montado. The purposeful sampling (Patton 2002) employed in this study was focused on current activities in rural areas carried out by its users. The 
following groups of current users were identified in the Montado area: landowners, workers, hunters, bee-keepers, mushroom pickers, inhabitants, new rural inhabitants, urban visitors and foreigners (Surová \& Pinto-Correia 2008). To take various standpoints into account, several members from each user group were interviewed. The requirement for the selection of respondents was their previous use of the Montado, and they were asked to answer according to the point of view of their main activity in the rural area. Collaboration with hunters, tourists, bee-keepers and landowner associations were established in the selected towns. Potential respondents were randomly selected from existing contacts in associations, and contacted personally or by telephone. Interviews, with those who accepted, were carried out individually. In all, 232 face-to-face interviews were carried out: workers $(\mathrm{N}=26)$, hunters $(\mathrm{N}=26)$, bee-keepers $(\mathrm{N}=29)$, mushroom pickers $(\mathrm{N}=12)$, foreign tourists $(\mathrm{N}=24)$, new rural inhabitants $(\mathrm{N}=31)$, rural inhabitants $(\mathrm{N}=28)$, urban dwellers from Lisbon $(\mathrm{N}=28)$ and landowners of the Cork Oak Montado ( $\mathrm{N}=28)$.

At the beginning of the interview, the respondent was given a short introduction on the purpose of the study. In order to gain information about the social characteristics of Montado users, socio-economic variables such as gender, age, education, number of family members and income were recorded during the interview. The interviewed users responded to several questions about activities practised in the Montado, namely: "What activities have you already practised in the Montado?", "When have you practised these activities in the Montado (during the week, weekend or holidays)?", "In which season?" With regard to existing difficulties and possible improvements related with their activities: "Do you feel any difficulties about visiting the Montado?", "What are the difficulties?" "Do you think that there are any improvements to be made with regard to the activities you practice in the Montado?", "Which improvements do you mean?" The landowners were asked to describe the current implementation of 'new' functions in the management of their farms: "What activities are currently performed on your estate?" and motivations for them: "Choose the main motivation for each activity to be performed on your estate from the following list: economy, tradition, social right, and ecology", "In the future, do you want to change the current situation with regard to the activities performed on your estate?" If the response was yes, the following question was asked: "What kind of change do you mean?"

Answers were subsequently analysed through descriptive statistics or, if related to open-ended questions, through content analysis. Answers to open-ended questions were broken down into a series of short phrases, and the phrases were sorted into categories that expressed similar meanings. The content analysis is adequate to identify concepts, key issues, themes and patterns in communicative texts, in order to arrive at interpretative and quantitative summaries of qualitative data (Patton 2002).

\section{Results}

Table 1 shows the socio-economic characteristics of respondents in this study. Most of the respondents were male. The main male activities practised in the Montado were hunting, bee-keeping and managing of the Montado system. The amount of respondents with graduate education, mainly in groups of tourists and new rural inhabitants, is significant.

Most respondents practised more than one type of activity in the Montado. The main activity of respondents was walking, followed by sightseeing by car and picnicking (Table 2). The favourite season for these activities is spring, except for hunting and mushroom picking, which are carried on predominantly during autumn and winter. By contrast, the Montado was less visited by respondents in summer. Weekends were referred as the best time to practice most activities.

The majority of interviewed land-users (53\%) felt some difficulties with visiting the Montado. From this group, approximately $74 \%$ of respondents complained about hindrances to access, specifically fences and closed gates, or out of respect for private property. In this last case, the respondents referred to lack of information about access possibilities to the area. $20 \%$ of the respondents mentioned problems with transport for getting to a Montado area, due to lack of own car or too much time needed. Concerns with safety due to lack of information about wild cattle, hunting zones or fire risk were mentioned by $13 \% .7 \%$ referred to lack of orientation facilities, as for instance signposting of walking paths and tourist information. About $7 \%$ of the group pointed out restrictions to mushroom and asparagus picking as problematic. 
Table 1 The socio-economic variables (categories) of respondents and their representation in percent.

\begin{tabular}{|c|c|c|c|c|c|c|c|c|c|c|c|}
\hline $\begin{array}{l}\text { Socio-economic } \\
\text { variables }\end{array}$ & Categories & $\begin{array}{c}\text { All } \\
(n=232)\end{array}$ & $\begin{array}{c}W \\
(n=26)\end{array}$ & $\begin{array}{c}\mathrm{H} \\
(\mathrm{n}=26)\end{array}$ & $\begin{array}{c}B \\
(n=29)\end{array}$ & $\begin{array}{c}M \\
(n=12) \\
\end{array}$ & $\begin{array}{c}F \\
(n=24)\end{array}$ & $\begin{array}{c}\mathrm{N} \\
(\mathrm{n}=31)\end{array}$ & $\begin{array}{c}R \\
(n=28) \\
\end{array}$ & $\begin{array}{c}U \\
(n=28)\end{array}$ & $\begin{array}{c}\mathrm{L} \\
(n=28)\end{array}$ \\
\hline \multirow[t]{2}{*}{ Gender } & Males & 66 & 62 & 92 & 100 & 83 & 42 & 32 & 46 & 50 & 96 \\
\hline & Females & 34 & 38 & 8 & 0 & 17 & 58 & 68 & 54 & 50 & 4 \\
\hline \multirow[t]{4}{*}{ Age } & $18-30$ years & 18 & 12 & 12 & 3 & 25 & 8 & 29 & 32 & 36 & 4 \\
\hline & $31-45$ years & 33 & 38 & 31 & 28 & 33 & 33 & 35 & 29 & 29 & 39 \\
\hline & $46-60$ years & 32 & 38 & 54 & 34 & 25 & 46 & 23 & 29 & 14 & 25 \\
\hline & $>60$ years & 18 & 12 & 4 & 34 & 17 & 13 & 13 & 11 & 21 & 32 \\
\hline \multirow[t]{4}{*}{ Education } & primary school & 15 & 35 & 12 & 41 & 25 & 0 & 0 & 11 & 14 & 0 \\
\hline & secondary school & 29 & 42 & 35 & 38 & 42 & 4 & 6 & 43 & 32 & 29 \\
\hline & high school & 11 & 4 & 12 & 3 & 0 & 17 & 10 & 18 & 11 & 18 \\
\hline & graduate & 45 & 19 & 42 & 17 & 33 & 79 & 84 & 29 & 43 & 54 \\
\hline \multirow[t]{3}{*}{ Family } & $1-2$ persons & 46 & 50 & 31 & 41 & 50 & 63 & 48 & 46 & 57 & 32 \\
\hline & 3-4 persons & 47 & 50 & 65 & 59 & 25 & 33 & 45 & 43 & 36 & 50 \\
\hline & $>4$ persons & 7 & 0 & 4 & 0 & 25 & 4 & 7 & 11 & 7 & 18 \\
\hline \multirow[t]{4}{*}{ Family income } & $<1000$ euro & 24 & 35 & 4 & 48 & 58 & 4 & 23 & 32 & 21 & 4 \\
\hline & $1000-2000$ euros & 38 & 46 & 50 & 31 & 33 & 38 & 29 & 43 & 39 & 36 \\
\hline & $2000-5000$ euros & 31 & 19 & 38 & 17 & 8 & 42 & 39 & 21 & 32 & 54 \\
\hline & $>5000$ euros & 6 & 0 & 8 & 3 & 0 & 17 & 10 & 4 & 7 & 7 \\
\hline
\end{tabular}

Explanatory notes: $W$ (workers), $H$ (hunters), B (bee-keepers), $M$ (mushroom pickers), $F$ (tourists), $N$ (new rural inhabitants), $U$ (urban dwellers), $L$ (landowners).

Concerning possible improvements, $89 \%$ of the interviewed land-users agreed they were needed. These were related with identification of walking paths, tourist and education information in the fields and access possibilities (36\% of respondents). Distribution of maps for walking paths, tourist guidebooks, information on the internet, promoting the Montado landscape ( $28 \%$ of respondents); improvement of public access to areas of interest that are privately owned ( $28 \%$ of respondents); organizing guided visits with explanation of diverse topics, cork debarking demonstration, environmental education of public about preservation of the Montado (16\% of respondents); development of infrastructures, bed \& breakfast accommodation in rural areas ( $7 \%$ of respondents); authorization of activities such picking mushrooms and asparagus (7\% of respondents); provision of amenities such as picnic tables, litter containers and rest areas (6\% of respondents) and construction of more dams in order to diversify the Montado landscape (4\% of respondents) were other topics mentioned. The majority of the bee-keepers interviewed suggested improvements of conditions for their activities, in particular identification of appropriate zones with shrub maintenance and free access for bee-keepers to these zones ( $66 \%$ of bee-keepers).

Table2 The activities practised in the Montado by respondents. Numbers in the table represent the percentage of all land-users interviewed.

\begin{tabular}{|c|c|c|c|c|c|c|c|c|c|c|c|}
\hline & \multicolumn{10}{|c|}{ Activities practiced in the Montado by respondents } & \multirow[b]{2}{*}{$\begin{array}{c}\text { bee- } \\
\text { keeping }\end{array}$} \\
\hline & walking & biking & jogging & hunting & $\begin{array}{l}\text { taking } \\
\text { pictures }\end{array}$ & picnick & $\begin{array}{l}\text { sight- } \\
\text { seeing } \\
\text { by car }\end{array}$ & $\begin{array}{c}\text { arom. } \\
\text { plants } \\
\text { picking }\end{array}$ & $\begin{array}{l}\text { mushr. } \\
\text { picking }\end{array}$ & $\begin{array}{l}\text { horse } \\
\text { riding }\end{array}$ & \\
\hline & 80 & 28 & 5 & 24 & 36 & 29 & 72 & 21 & 19 & 5 & 19 \\
\hline autumn & 43 & 14 & 3 & 19 & 16 & 6 & 35 & 5 & 12 & 1 & 6 \\
\hline winter & 33 & 10 & 2 & 20 & 13 & 11 & 32 & 2 & 10 & 0 & 4 \\
\hline spring & 55 & 16 & 4 & 0 & 23 & 21 & 39 & 15 & 6 & 2 & 11 \\
\hline summer & 24 & 12 & 2 & 5 & 12 & 5 & 37 & 5 & 0 & 0 & 8 \\
\hline week & 17 & 7 & 2 & 3 & 7 & 7 & 25 & 5 & 4 & 0 & 10 \\
\hline weekend & 50 & 20 & 3 & 20 & 22 & 18 & 33 & 15 & 15 & 4 & 9 \\
\hline holidays & 13 & 2 & 0 & 0 & 7 & 4 & 13 & 1 & 0 & 0 & 0 \\
\hline
\end{tabular}

A type of 'new' activities incorporated into the estate management of interviewed landowners is presented in Table 3. Hunting was widely included, due to its economic benefit for landowners. Activities such as mushroom picking and bee-keeping were included in about half of the estates, due predominately to social and partly traditional reasons. Rural tourism and educational activities were 
also available on a few properties on account of economic profit. Few of the landowners interviewed mentioned voluntary authorization of free access for the public. The results obtained by qualitative analysis of landowners' answers with regard to management changes in the future highlighted three types of attitudes to 'new' rural functions. About half of the landowners have put into practice some of the 'new' rural functions or intend to include them in their estate's management. A part of the landowners interviewed (18\%) have traditionally allowed free access to their properties and do not intend to make any changes in this state of affairs or include other 'new' functions in their management. Others (32\%) do not currently authorize free access of public and have no intention to change this situation in the future. Few landowners perceived the 'new' activities as a further complication for their purely productive management of their estate.

Table 3 Implementation of activities in the management of interviewed landowners' estates and the main landowners' motivation for each function.

\begin{tabular}{lccccc}
\hline \multicolumn{1}{c}{ Activities implemented } & $\begin{array}{c}\text { Properties } \\
\%\end{array}$ & \multicolumn{4}{c}{ Main landowners' motivation } \\
\cline { 3 - 6 } & & economic & tradition & social & ecological \\
\hline hunting & 89 & 61 & 11 & 0 & 18 \\
mushroom picking & 54 & 4 & 7 & 39 & 0 \\
beekeeping & 46 & 0 & 11 & 32 & 4 \\
rural tourism (accomodation) & 29 & 18 & 0 & 7 & 4 \\
voluntary free access for public & 18 & 0 & 4 & 14 & 0 \\
pedagogic activities & 14 & 11 & 4 & 0 & 0 \\
\hline
\end{tabular}

\section{Discussion and concluding remarks}

This paper aimed at surveying the use and assessment of 'new' rural functions in the Montado, both by its land-users and landowners. After an examination of visitor profiles, the results show that a diversity of people use the Montado areas for leisure. The abundance of visitors with higher education is noteworthy. The fact of fewer visits during the summer season can be ascribed to the climate conditions with dry and very hot summers and to increased fire risk in this season. Walking was the main activity practised by respondents, followed by sightseeing by car, which is probably related with the high scenic attractiveness of this landscape type: an undulating terrain allowing different panoramic views to this open savanna-like landscape, with changing densities of trees and changing pasture composition.

The Montado is appreciated for different activities, and there is an increasing pressure from today's society for a more socially sensitive management. The majority of respondents expressed some difficulties in visiting the Montado areas, mainly due to access limitations. This problem is notable in the past decade, when large open areas that existed in the past, perceived as being open to the public, are now changing into fenced areas, with access restrictions or without information on access possibilities. The fencing of estates allows for the control of livestock grazing areas, but could also contribute to the control of visitor access during the summer. This control could be a solution regarding fire risk and application of property rights for externalities such as mushroom picking and hunting, which could then be paid by users. The increased consideration of economic interests concerning these externalities leads to increasing pressure by landowners to privatize these goods (Merlo and Croitoru, 2005). Even this fencing trend could be perceived as one step in managing social functions through the control of visits, if it were to be followed by subsequent steps, such as the improvements mentioned by land-users in this study. The improvement of infrastructures, such as walking paths and route indicators, signposting in the fields, and the setting up of interpretation panels, could provide information for visitors so they could discover more about the landscape they are enjoying. These improvements would additionally allow for a higher degree of independence for the occasional visitor, who would not need to be part of large guided groups of visitors. This could consequently increase the quality of the experience by visitors.

A great part of landowners are still mainly engaged in productive activities as these are their main source of income. Yet, probably due to its long tradition in rural areas, hunting is practiced in most estates, bringing some economic input. Regarding the landowners' attitudes about 'new' rural functions, a better preparation to face the current social demands is needed. The important role of "communication" between stakeholders is stressed by various authors (e.g. Brunori and Rossi, 2007, Konijnendijk, 2000). More communication would most probably help to understand the restrictions 
imposed, or desired, by landowners, and on the other hand, it would enhance farmers' understanding about what the public expects and demands from rural areas.

Economic incentives for landowners could also improve the current situation, as for example support for the development of 'new' functions, such as payments and grants for the upkeep of paths and other facilities; or compensation for additional work undertaken to create conditions for public access. But still the economic incentives should be accompanied by other tools, such as best practice guides produced as a result of cross sector collaboration.

The present study contributes to a reflection about the current situation of 'new' rural functions in the Montado in Southern Portugal, and brings to light several aspects which are important for the successful inclusion of these functions into the management of private estates within the Montado system. Besides the economic benefits for landowners that accrue from 'new' rural functions, another support measure would concist in providing help for landowners in the implementation process. Essential is furthermore a clear definition of rights and responsibilities of land-users and landowners concerning the functions mentioned. Somehow the need for these various measures in order to improve the multifunctional use of the Montado appears as an evidence, since the most important potential is there: the attractiveness of the Montado, and the possible and already existing link between commodity and non-commodity functions.

\section{References}

Brunori, G, Rossi, A, 2007. Differentiating countryside: Social representations and governance patterns in rural areas with high social density: The case of Chianti, Italy, Journal of Rural Studies, 23, 183-205

European Landscape Convention, 2000. (Florence).

Fonseca, A., 2004. O Montado no Alentejo (Séc. XV a XVIII) (Portugal, Edições Colibri).

Gomez-Limon J. and Fernandez L.J.V., 1999. Changes in use and landscape preferences on the agricultural-livestock landscapes of the central Iberian peninsula (Madrid, Spain), Landscape and Urban Planning, 44, 165-175

Merlo, M; Croitoru, L. (Eds.), 2005. Valuing Mediterranean Forests, Towards Total Economic Value. Wallingford, Oxfordshire: CABI Publishing, CAB International.

Konijnendijk, C.C., 2000. Adapting forestry to urban demands - role of communication in urban forestry in Europe, Landscape and Urban Planning, 52, 2-3, 89-100

Patton, M.Q., 2002. Qualitative Research and Evaluation Methods (3rd ed.). Thousand Oaks, CA: Sage Publication, Inc.

Pinto-Correia, T., 1993. Threatened Landscape in Alentejo, Portugal: the "Montado" and other "AgroSilvo-Pastoral" Systems, Landscape and Urban Planning, 24, 43-48

Pinto-Correia, T. and Mascarenhas, J., 1999. Contribution for the extensification/intensification debate: what is happening to the Portuguese Montado?, Landscape and Urban Planning, 46, 125-131

Pinto-Correia T. and Vos W., 2004. Multifunctionality in Mediterranean landscapes - past and future. In: Jongman R.H.G. (Ed.), The New Dimensions of the European Landscape, Wageningen UR Frontis Series, Springer, 135-164.

Plieninger, T., Modolell y Mainou, J. and Konold, W., 2004. Land manager attitude toward management, regeneration and conservation of Spanish holm oak savannas (dehesas), Landscape and Urban Planning, 3, 185-198

Surová, D. and Pinto-Correia, T., 2008. Landscape preferences in the cork oak Montado in the region of Alentejo, southern Portugal: searching for valuable landscape characteristics for different user groups, Landscape Research, in press 